\title{
Comparative Geomorphometric Approach to Understand the Hydrological Behaviour and Identification of the Erosion Prone Areas of a Coastal Watershed Using RS and GIS Tools
}

Kuldeep Singh Rautela ( $\square$ kuldeeprautela007@gmail.com )

Punjab Engineering College

Mohit Kumar

Punjab Engineering College

Varun Khajuria

Punjab Engineering College

M. A. Alam

Punjab Engineering College

\section{Research Article}

Keywords: Decision-makers, Erosion rate, surface runoff, Remote sensing, Western ghats

Posted Date: October 15th, 2021

DOI: https://doi.org/10.21203/rs.3.rs-966853/v1

License: (c) (i) This work is licensed under a Creative Commons Attribution 4.0 International License. Read Full License

Version of Record: A version of this preprint was published at Discover Water on January 5th, 2022. See the published version at https://doi.org/10.1007/s43832-021-00009-z. 


\section{Abstract}

Assessment of the geomorphometric parameters using RS and GIS tools assumes an imperative part in routing the runoff and the remaining hydrological processes. The current study demonstrates a geospatial model based on geomorphometric parameters for the categorization of surface runoff and identification of the erosion-prone areas within the watershed. The 4th order Kuttiyadi river is dominated by a dendritic to semi-dendritic drainage pattern in the subwatersheds. The linear aspect of subwatersheds indicates the subwatersheds have a structurally permeable surface and subsurface materials with uniform lithology. The aerial and relief aspects of the subwatersheds shows fine drainage texture, gentle slopes, delayed peak flow, flatter hydrograph, and large time of concentration which indicates subwatersheds are quite capable to manage flash floods during storm events. The estimated values of surface runoff and sediment production rate are range from 2.13-32.88 $\mathrm{km}^{2}-\mathrm{cm} / \mathrm{km}^{2}$ and 0.0004-0.017 Ha-m/100km²/year respectively and suggest that $\mathrm{SW}_{1}$ will generate more surface runoff and prone to soil erosion followed by $\mathrm{SW}_{2} \mathrm{while}$ compare to the other subwatersheds. As a result of this paper, reliable assessment of peak flooding and relevant basic knowledge will be provided to decision-makers and policymakers responsible for establishing suitable policies and sustainable land use practices for the watershed.

\section{Introduction}

Rivers played a significant role in human civilization throughout the centuries [1]. As a result of their ecological and economic importance, hydrological processes have a great deal of interest among the public [2,3]. Anthropogenic as well as natural factors influence hydrological processes such as shifting and intensity of rainfall occurring, sedimentation, consecutive droughts, and floods, etc; [4]. Changes in the climatic process in the watershed of spring/rain-fed rivers may alter the change in land use, rapid drying of springs, agricultural shifting, etc; as a result of these changes, the hydrological properties of soil, dynamics of surface and sub-surface flows, and the frequency of floods are likely to be changed $[3,5]$. Urbanization exacerbates the problem by allowing less infiltration and intensifying surface runoff and decreasing the time lag between rainfall and surface runoff [6]. Streamflow and soil erosion are directly influenced by the intensity and amount of rainfall in a watershed which is further used to determine the sediment yield [7]. The sediment fluxes significantly affect the function of a river, as they affect the structure of channels, the development of deltas, the quality of water, geochemical cycles, and habitats in a river ecosystem [8,9]. It is vital to understand how sediments are transported by rivers in relation to morphodynamics, hydrology, erosion rates, and sediment transfer dynamics within the specific watershed [10]. In several parts of the world, erosion rates have been accelerated because of anthropogenic changes at a global level. This has had a negative impact both on soil dynamics and sediment flow [11].

Morphometry is the science of observing, measuring, and analyzing landform's dimensions based on the shape, size, and other features of the earth's surface $[12,13]$. A geomorphometric analysis has been widely applied to understand the characteristic features of a watershed, such as drainage characteristics and quantitative morphological characteristics [14]. In terms of drainage watersheds and their connected drainage networks, morphometric parameters determine the form and its structure $[15,16]$. The linear, aerial, and relief contributions can be determined via a measurement of the watershed and slope component [17]. Linear aspects of the Morphometric parameters, such as stream numbers, stream lengths, and stream patterns, are key components in comprehending a watershed's hydrological response [18]. A watershed is considered a fundamental conveyer of surface runoff and erosional landscape elements. Further, in the watershed continuous association of land units and water units takes place [19]. Hydrologists have utilized the watershed as a primary unit to study the hydrological response. In this regard, compared with individual channels or conflicting sections, geomorphometric investigations at the scale of the little watershed are more profitable [14]. The aerial aspect of the geomorphometric parameters has considerable influence on the surface

Page $2 / 20$ 
runoff parameters such as travel time, concentration-time, time-lag, and intensity of land erosion cycles, which can be further anticipated with greater precision [20]. An investigation of geomorphometric features in river watersheds without gauges can provide insights into those variables that influence hydrological characteristics [21]. There are several factors influencing sediment transport in a watershed, such as relief, stream density, streamflow, terrain roughness, watershed shape, subsurface flow, rainfall, soil permeability, and water-holding capacity [22, 23]. Additionally, anthropogenic factors such as deforestation, afforestation, rapid urbanization, and inappropriate land use and management can also influence the hydrological response and erosion rate of a watershed [24]. Sedimentation and ecological degradation normally increase as a result of unsuitable land use and management practices [25]. It is therefore possible to quantify erosion rates in the watershed using sediment fluxes and other temporal features to understand erosion dynamics and assist in the development of river basins sustainably by monitoring these sediment fluxes over time.

Although in India, management of land and water resources on a watershed has been given top-most priority but still, most of the states of northern to southern regions of India are poorly managed to conserve water, soil, and the nutrient state as per watershed management plan $[26,27]$. It is important to develop appropriate strategies and determine priorities for monitoring the watershed responses towards controlling soil erosion and flooding with some preliminary information about the spatio-temporal variations in the hydrological response dynamics of different subwatersheds [28]. The value of such conservation practices can be enhanced through the quantification of morphometric parameters pertaining to a watershed. Remote Sensing (RS) tools along with Geographical Information System (GIS) provide a more accurate and more effective application to find out the hydrological response of a watershed [29, 30]. There have been numerous studies on erosion data at various scales in different parts of India, but no one has explored the hydrological behavior of a coastal watershed as well as identifying areas of high erosion by examining the sediment production rate and surface runoff. This study attempts to fill the research gap and will investigate hydrological behavior and identification of the zone of high erosion in the watershed by applying a mathematical model concerning the geo-morphometric analysis at three different aspects of a Kuttiyadi river watershed. In addition, the data will provide key information regarding sustainable resource management for public benefit.

\section{Study Area}

Kuttiyadi River (Fig. 1 and 2) starts from the Narikota Ranges on the Western inclines near the hilly terrain of Waynad; which is a piece of Western Ghats, at a height of 1220 meters over the mean sea level (MSL). The river moves along through Badagara, Qulandy, and Kozhikode Taluks in Kerala before it merges with the Arabian Sea at Kottakal. Kuttiyadi River and its tributaries drain an area of $436 \mathrm{~km}^{2}$. The average annual precipitation received by the watershed is 5170 $\mathrm{mm}$ of which $30 \%$ of the average annual precipitation is received from the north-east (NE) monsoon and $60 \%$ of the average annual precipitation is received from the south-west (SW) monsoon [31]. The average ambient temperature in the Watershed ranges from 30-33.5区C.

\section{Methodology}

Remote Sensing (RS) along with GIS tools have been widely used to determine the morphometric parameters of the Kuttiyadi River watershed. The watershed parameters are analyzed by digital imagery using ArcGIS 10.6.1. The data sets were used for the analysis as follows:

i. Digital Elevation Model of SRTM $30 \mathrm{~m}$ spatial resolution.

ii. Topographical maps of Kerala at 1: 2,50,000 scale.

iii. Google base map.

Page $3 / 20$ 
The drainage generation categorization of the Kuttiyadi watershed was made up by using SRTM 30m DEM (Fig. 3). The extraction of the watershed drainage map was prepared by the ArcHydro tool using ArcGIS 10.6.1. The drainage pattern was also digitized by using topographical maps and the satellite imaginary overlapped with each other. Sinks in the Digital Elevation Model (DEM) were recognized and filled up by using the tool of fill sinks to identify and proper determination of the accumulation and direction of the flow. The watershed boundary was generated by defining the outlet point at the outlet. Similarly, the same process was repeated was for the sub-watershed of the Kuttiyadi watershed along the path of the main course. The raster datasets of the watershed and sub-watershed were converted into vector data sets in the form of polylines to polygon and projected into the WGS 1984 UTM Zone- 43N for calculation of the watershed area, perimeter, and stream lengths. The other geo-morphometric parameters such as linear, relief, and aerial parameters are analyzed using the simple mathematical formulae (Table 1)[14, 32-36].

\subsection{Geo-morphometric Parameters}

The analyzed geo-morphometric parameters of the Kuttiyadi watershed were categorized into three broad categories as follows:

i. Liner Aspects: It includes all the linear Morphometric parameters of a basin such as stream nos. $\left(\mathrm{N}_{\mathrm{u}}\right)$, length of streams $\left(L_{u}\right)$, mean stream lengths $\left(L_{s m}\right)$, stream length ratios $\left(R_{l}\right)$, Bifurcation, and Mean Bifurcation ratio $\left(R_{b}\right.$ and $\left.\mathrm{R}_{\mathrm{bm}}\right)$.

ii. Relief Aspects: It includes the parameters which are change with the elevation of a basin such as relative relief $(R)$, relief ratio $\left(R_{h}\right)$, and Ruggedness No. $\left(R_{n}\right)$.

iii. Aerial Aspects: It includes the parameters which are changes with the aerial distance of a basin such as a Drainage density $\left(D_{d}\right)$, Texture ratio $(T)$, Stream Frequency $\left(F_{s}\right)$, Elongation ratio $\left(R_{e}\right)$, Circularity ratio $\left(R_{c}\right)$, Form factor $\left(R_{f}\right)$, Rotundity Factor $\left(R_{f}\right)$, Texture Ratio $(T)$, Shape index $\left(S_{i}\right)$, Length of overland flow $\left(L_{o f}\right)$, Constant Channel maintenance $(\mathrm{C})$.

Table 1. Methods of determining Morphometric parameters 
Table 1

Mathematical formulae for the geomorphometric parameters based on linear, relief and aerial aspects

\begin{tabular}{|c|c|c|c|c|}
\hline S.No. & & $\begin{array}{l}\text { Morphometric } \\
\text { Parameters }\end{array}$ & Formule & References \\
\hline 1. & \multirow{6}{*}{$\begin{array}{l}\text { Liner } \\
\text { Parameters }\end{array}$} & Stream order (U) & Hierarchical rank & [38] \\
\hline 2. & & Stream length $\left(L_{u}\right)$ & Length of stream & [39] \\
\hline 3. & & $\begin{array}{l}\text { Mean stream length } \\
\left(\mathrm{L}_{\mathrm{sm}}\right)\end{array}$ & $L_{s m}=L_{u} / N_{u}$ & [38] \\
\hline 4. & & Stream length ratio $\left(R_{\mathrm{L}}\right)$ & $R_{L}=L_{u} / L_{u-1}$ & [39] \\
\hline 5. & & Bifurcation ratio $\left(\mathrm{R}_{\mathrm{b}}\right)$ & $R_{b}=N_{u} / N_{u+1}$ & [41] \\
\hline 6. & & $\begin{array}{l}\text { Mean bifurcation } \\
\text { ratio }\left(\mathrm{R}_{\mathrm{bm}}\right)\end{array}$ & Average of bifurcation ratios of all orders & [37] \\
\hline 7. & \multirow[t]{3}{*}{$\begin{array}{l}\text { Relief } \\
\text { Parameters }\end{array}$} & Watershed relief $\left(\mathrm{W}_{\mathrm{h}}\right)$ & $\begin{array}{l}\text { The vertical distance between the lowest and } \\
\text { highest points of the watershed. }\end{array}$ & {$[41]$} \\
\hline 8. & & Relief ratio $\left(R_{h}\right)$ & $\mathrm{R}_{\mathrm{h}}=\mathrm{W}_{\mathrm{h}} / \mathrm{L}_{\mathrm{b}}$ & [41] \\
\hline 9. & & $\begin{array}{l}\text { Ruggedness number } \\
\left(R_{n}\right)\end{array}$ & $R_{n}=W_{h} \times D_{d}$ & [41] \\
\hline 10. & \multirow[t]{11}{*}{$\begin{array}{l}\text { Aerial } \\
\text { Parameters }\end{array}$} & Drainage density $\left(D_{d}\right)$ & $D=L_{u} / A$ & [39] \\
\hline 11. & & Drainage Texture $\left(\mathrm{R}_{\mathrm{t}}\right)$ & $R_{t}=N_{u} / P$ & [42] \\
\hline 12. & & Stream frequency $\left(\mathrm{F}_{\mathrm{s}}\right)$ & $F_{s}=N_{u} / A$ & [39] \\
\hline 13. & & $\begin{array}{l}\text { Length of overland } \\
\text { flow }\left(L_{g}\right)\end{array}$ & $L_{g}=1 / D_{d} * 2$ & [39] \\
\hline 14. & & $\begin{array}{l}\text { Constant channel } \\
\text { maintenance }(C)\end{array}$ & $C=1 / D_{\mathrm{d}}$ & {$[41]$} \\
\hline 15. & & Elongation ratio $\left(\mathrm{R}_{\mathrm{e}}\right)$ & $R_{e}=\left(2 / L_{b}\right) * \operatorname{sqrt}(A / \Pi)$ & {$[41]$} \\
\hline 16. & & Circulatory ratio $\left(\mathrm{R}_{\mathrm{c}}\right)$ & $R_{C}=4 * \Pi * A / L_{p}^{2}$ & [38] \\
\hline 17. & & Form factor $\left(F_{f}\right)$ & $R_{f}=A / L_{b}^{2}$ & [39] \\
\hline 18. & & $\begin{array}{l}\text { Compactness } \\
\text { Coefficient }\left(C_{c}\right)\end{array}$ & $C_{c}=0.282 * L_{p} / \operatorname{sqrt}(A)$ & [43] \\
\hline 19. & & Rotundity factor $\left(R_{f}\right)$ & $R_{f}=L_{b}^{2} / 4 A$ & {$[44]$} \\
\hline 20. & & Shape index $\left(\mathrm{S}_{\mathrm{i}}\right)$ & $S_{w}=L_{b s}^{2} / A$ & [40] \\
\hline
\end{tabular}




\begin{tabular}{|c|c|c|}
\hline S.No. & $\begin{array}{l}\text { Morphometric } \\
\text { Parameters }\end{array}$ & References \\
\hline \multicolumn{3}{|l|}{ Where; } \\
\hline \multicolumn{3}{|c|}{$L u=$ Total stream length of order " $u$ " } \\
\hline \multicolumn{3}{|c|}{$N u=$ Total no. of stream segments of order " $u$ " } \\
\hline \multicolumn{3}{|c|}{$R L=$ Stream length ratio } \\
\hline \multicolumn{3}{|c|}{$L u-1=$ The total stream length of its next lower order } \\
\hline \multicolumn{3}{|c|}{$R b=$ Bifucation ratio, } \\
\hline \multicolumn{3}{|c|}{$N u+1=$ Number of segments of the next higher order } \\
\hline \multicolumn{3}{|c|}{ Wh=Watershed relief $(\mathrm{km})$} \\
\hline \multicolumn{3}{|c|}{$\mathrm{Lb}=$ Watershed length $(\mathrm{km})$} \\
\hline \multicolumn{3}{|c|}{ Lbs= Watershed length along the main stream $(\mathrm{km})$} \\
\hline \multicolumn{3}{|c|}{$\mathrm{Dd}=$ Drainage density $\left(\mathrm{km}^{-1}\right)$} \\
\hline \multicolumn{3}{|c|}{$A=$ Area of the Watershed $\left(\mathrm{km}^{2}\right)$} \\
\hline \multicolumn{3}{|c|}{$P=$ Perimeter $(\mathrm{km})$} \\
\hline$\Pi=3.14$ & & \\
\hline
\end{tabular}

\subsection{Watershed surface runoff Sediment Production Rate}

The Surface runoff and Sediment Production Rate has been estimated for the categorization of the zones which convey high surface runoff to the watershed outlet. A similar approach was also used for the identification of the erosion-prone areas within the watershed. A mathematical model was used based on the Morphometric parameters that have been applied to the subwatersheds for the quantification of runoff and sediment production rate $[3,45,46]$.

$$
\begin{aligned}
\log Q=2238.43+22.12\left\{\log \left(100+R_{f}\right)\right\}-608.28\left\{\log \left(100+R_{c}\right)\right\} \\
-530.02\left\{\log \left(100+C_{c}\right)\right\} \\
\log S P R=4919.80+48.64\left\{\log \left(100+R_{f}\right)\right\}-1337.77\left\{\log \left(100+R_{c}\right)\right\} \\
\quad-1166.64\left\{\log \left(100+C_{c}\right)\right\}
\end{aligned}
$$

Where; $Q$ is watershed runoff $\left(\mathrm{km}^{2}-\mathrm{cm} / \mathrm{km}^{2}\right)$, SPR is the sediment production rate $\left(\mathrm{Ha}-\mathrm{m} / 100-\mathrm{km}^{2} /\right.$ year) for the unit area, $R_{f}, R_{c}$ and $C_{c}$ are the Rotundity factor, Circulatory ratio, and Compactness coefficient of the watershed respectively. The estimated runoff and the sediment production rate of the watersheds provided by the model are in the log scale. By taking the antilog of the estimated values, the actual runoff and sediment production rates of the watershed can be computed. 


\section{Results And Discussion}

\subsection{Basic watershed parameters}

The total $436 \mathrm{~km}^{2}$ area of the upper Kuttiyadi river watershed is subdivided into 6 small subwatersheds along the main river (Table 2). The area and perimeter of subwatersheds range from $49.60 \mathrm{~km}^{2}$ to $128.35 \mathrm{~km}^{2}$ and $37.50 \mathrm{~km}$ to 115.4 $\mathrm{km}$ respectively (Table 2 ). The elevation of the basin ranges from $15 \mathrm{~m}$ to $1542 \mathrm{~m}$ from amsl. A major area of this watershed is covered with flat topography and high plantations (Fig. $4 \mathrm{c}$ and $4 \mathrm{~d}$ ).

Table 2

Important watershed characteristics

\begin{tabular}{|lllllll|}
\hline S.No. & $\mathrm{E}_{\min }(\mathrm{km})$ & $\mathrm{E}_{\max }(\mathrm{km})$ & $\mathrm{R}_{\mathrm{r}}$ & $\mathrm{L}_{\mathrm{b}}(\mathrm{km})$ & $\mathrm{A}\left(\mathrm{km}^{2}\right)$ & $\mathrm{L}_{\mathrm{p}}(\mathrm{km})$ \\
\hline $\mathrm{SW}_{\mathbf{1}}$ & 0.017 & 0.563 & 0.546 & 16.96 & 128.35 & 60.78 \\
$\mathrm{SW}_{\mathbf{2}}$ & 0.017 & 1.038 & 1.021 & 14.87 & 97.07 & 56.82 \\
$\mathrm{SW}_{\mathbf{3}}$ & 0.038 & 1.291 & 1.253 & 13.04 & 49.6 & 45.4 \\
$\mathrm{SW}_{\mathbf{4}}$ & 0.033 & 1.542 & 1.509 & 17.92 & 68.12 & 115.4 \\
$\mathrm{SW}_{\mathbf{5}}$ & 0.015 & 0.692 & 0.677 & 19.03 & 61.97 & 88.64 \\
\hline $\mathrm{SW}_{\mathbf{6}}$ & 0.015 & 0.027 & 0.012 & 9.25 & 31.03 & 37.5 \\
\hline
\end{tabular}

\subsection{Linear Aspects}

The 4th order Kuttiyadi river is made up of 96 different lower-order streams. The highest stream order among the 6 subwatersheds is 4 th shown by the 4 watersheds named $\mathrm{SW}_{1}, \mathrm{SW}_{2}, \mathrm{SW}_{5}$, and $\mathrm{SW}_{6}$ respectively, and while the remaining two watersheds have the highest stream of order 3rd named $\mathrm{SW}_{3}$ and $\mathrm{SW}_{4}$ (Table 3 ). The discharge carrying capacity of a stream and the flowing velocity increase with the stream order. In addition to contributing to greater sediment loads to the river, higher velocity and discharge exacerbate the erosion of the river bed and banks [47]. Additionally, it is observed that the number of stream segments decreases as the stream order increases and vice versa [39]. The stream length $\left(\mathrm{L}_{\mathrm{u}}\right)$ of the stream segments is maximum in the case of first-order streams and stream length decreases as the order of streams increases [48]. The mean stream length $\left(\mathrm{L}_{\mathrm{sm}}\right)$ of any given order is greater than that of the lower order streams [39]. The higher stream length and mean stream length is shown by the $\mathrm{SW}_{1}$ and $\mathrm{SW}_{4}$ (Table 3). As a result, these two watersheds $\mathrm{SW}_{4}$ are capable of conveying less surface runoff volume to the mainstream but due to high vegetal cover, uniform slope, and loamy soil, a large amount of surface runoff will infiltrate through cracks under the dry conditions of the soil. However, The lag time of the $\mathrm{SW}_{6}$ has very little as compared to others because it has less watershed area and perimeter, and also the catchment has very few stream lengths (Table 3$)$. Stream length ratio $\left(R_{L}\right)$ is the ratio of the mean stream length of the individual stream segment to the next lower order stream segment [39]. A larger stream length ratio indicates a greater potential to carry a large volume of runoff [14]. This study showed that watershed uplift is negligible, with uniform lithology throughout the watershed. The Mean bifurcation ratio $\left(R_{b m}\right)$ of the 6 subwatersheds of the Kuttiyadi river is 2.33 2.13, 2.00, 3.28, 2.63, and 1.75 for SW1, SW2, SW3, SW4, SW5, and SW6 respectively (Table 3 ). There is a possibility in the watershed that the mean Bifurcation ratio may not remain constant from one order to the next because of variations in geometry and lithology [49]. The low $\mathrm{R}_{\mathrm{bm}}$ indicates the delay in the peak of hydrograph ie; the time of concentration is more and the high $\mathrm{R}_{\mathrm{bm}}$ indicates the early rise in the hydrograph ie; the time of concentration is less so that the $\mathrm{R}_{\mathrm{bm}}$ is sometimes used to identifying the watersheds which are responsible 
for flash flooding $[14,50]$. Overall the $\mathrm{R}_{\mathrm{bm}}$ of the subwatersheds is less showing the delayed peak in the hydrographs. The linear aspect of geo-morphometric parameters demonstrates that the watershed area depends only on the drainage characteristics for the runoff movement.

Table 3

Computed values of the Linear aspect of the geo-morphometric parameters for the sub-watershed of the Kuttiyadi river

\begin{tabular}{|c|c|c|c|c|c|c|c|}
\hline S.No. & U & $\mathbf{N}_{\mathbf{u}}$ & $\mathrm{L}_{\mathrm{u}}(\mathrm{km})$ & $\mathrm{L}_{\mathrm{sm}}(\mathrm{km})$ & $\mathbf{R}_{\mathrm{L}}$ & $\mathbf{R}_{\mathrm{b}}$ & $\mathbf{R}_{\mathrm{bm}}$ \\
\hline \multirow[t]{4}{*}{$s W_{1}$} & 1 & 20 & 40 & 2 & 1 & 3.33 & 2.33 \\
\hline & 2 & 6 & 19.72 & 3.29 & 0.493 & 3 & \\
\hline & 3 & 2 & 7.61 & 3.81 & 0.39 & 2 & \\
\hline & 4 & 1 & 6.87 & 6.87 & 0.90 & 1 & \\
\hline \multirow[t]{4}{*}{$s W_{2}$} & 1 & 12 & 29.68 & 2.47 & 1 & 4 & 2.13 \\
\hline & 2 & 3 & 21.59 & 7.20 & 0.73 & 1.5 & \\
\hline & 3 & 2 & 3.84 & 1.92 & 0.18 & 2 & \\
\hline & 4 & 1 & 4.52 & 4.52 & 1.18 & 1 & \\
\hline \multirow[t]{4}{*}{$\mathrm{SW}_{3}$} & 1 & 6 & 16.66 & 2.78 & 1 & 3 & 2.00 \\
\hline & 2 & 2 & 10.21 & 5.11 & 0.61 & 2 & \\
\hline & 3 & 1 & 0.27 & 0.27 & 0.02 & 1 & \\
\hline & 4 & - & - & - & - & - & \\
\hline \multirow[t]{4}{*}{$\mathrm{sW}_{4}$} & 1 & 17 & 37.95 & 2.23 & 1 & 2.83 & 3.28 \\
\hline & 2 & 6 & 10.5 & 1.75 & 0.27 & 6 & \\
\hline & 3 & 1 & 14.23 & 14.23 & 1.36 & 1 & \\
\hline & 4 & - & - & - & - & - & \\
\hline \multirow[t]{4}{*}{$\mathrm{sW}_{5}$} & 1 & 13 & 26.7 & 2.05 & 1 & 6.5 & 2.63 \\
\hline & 2 & 2 & 2.97 & 1.49 & 0.11 & 1 & \\
\hline & 3 & 2 & 16.15 & 8.08 & 5.43 & 2 & \\
\hline & 4 & 1 & 5.86 & 5.86 & 0.36 & 1 & \\
\hline \multirow[t]{4}{*}{$\mathrm{sW}_{6}$} & 1 & 6 & 11.83 & 1.97 & 1 & 3 & 1.75 \\
\hline & 2 & 2 & 6.7 & 3.35 & 0.57 & & \\
\hline & 3 & 2 & 3.21 & 1.60 & 0.48 & & \\
\hline & 4 & 1 & 2.39 & 2.39 & 0.75 & & \\
\hline
\end{tabular}

\subsection{Relief Aspects}

In a watershed, relief indicates the difference between its maximum and minimum elevation. It is important for a watershed to examine its relief to investigate the behavior of surface runoff [51]. The results show the watershed relief of the $\mathrm{SW}_{4}$ is quite high as compared to the others (Table 4). It shows there is a lot of variation between maximum and 
minimum elevation. This may happen if the watershed is elongated enough or either the watershed having very steep slopes. An elongated watershed shows a delayed hydrograph peak with a larger time of concentration [14]. However, out of the total watershed area, $127.35 \mathrm{~km}^{2}$ area falls under less than $15 \otimes, 73.20 \mathrm{~km}^{2}$ area falls under $15-30 \otimes$ slope, $29.29 \mathrm{~km}^{2}$ area falls under $30-45 \bigotimes$ slope and only $3.79 \mathrm{~km}^{2}$ area falls under the greater than $45 \otimes$ slope (Fig. 2). The maximum area of the watershed lies under the low relief and less slope. The results also indicate that the study area has been no probable uplift due to the uniform geology and lithology. Quantitatively, the relief ratio of a watershed measures the overall steepness [51]. Also, it is a primary indicator of erosion intensity which operates on the mountainous slopes [52]. Relief ratio increases with decreasing the area and size of a watershed [53]. The computed value of the subwatersheds shows very low values of relief ratio. So, the subwatersheds are less prone to erosion (Table 4). The subwatersheds have relatively very low erosion based on the minor change in $R_{h}$. The ruggedness number $\left(R_{n}\right)$ indicates the structural complexity of the watershed terrain with the relief $\left(W_{h}\right)$ and drainage density $\left(D_{d}\right)$. It also describes the areas which are prone to soil erosion [65]. The computed values of $R_{n}$ for the subwatersheds $S W_{1}, S W_{2}$, $\mathrm{SW}_{3}, \mathrm{SW}_{4}, \mathrm{SW}_{5}$, and $\mathrm{SW}_{6}$ are $0.08,0.16,0.23,0.46,0.14$ and 0.04 respectively (Table 4). The lesser values of the $\mathrm{R}_{\mathrm{n}}$ indicate the subwatersheds are less prone to the soil erosion associated with the low drainage density, low relief, and gentle slopes (Fig. 2a and 4b).

Table 4

Computed values of the Relief aspect of the geo-morphometric parameters for the subwatershed of the Kuttiyadi river

\begin{tabular}{|llll|}
\hline S.No. & $\mathrm{W}_{\mathrm{h}}$ & $\mathrm{R}_{\mathrm{h}}$ & $\mathrm{R}_{\mathrm{n}}$ \\
\hline $\mathrm{SW}_{\mathbf{1}}$ & 546 & 0.03 & 0.08 \\
$\mathrm{SW}_{\mathbf{2}}$ & 1021 & 0.07 & 0.16 \\
$\mathrm{SW}_{\mathbf{3}}$ & 1253 & 0.10 & 0.23 \\
$\mathrm{SW}_{\mathbf{4}}$ & 1509 & 0.08 & 0.46 \\
$\mathrm{SW}_{\mathbf{5}}$ & 677 & 0.04 & 0.14 \\
\hline $\mathrm{SW}_{6}$ & 192 & 0.02 & 0.04 \\
\hline
\end{tabular}

\subsection{Aerial Aspects}

The drainage density $\left(D_{d}\right)$ of the subwatersheds of the Kuttiyadi river is $0.145,0.154,0.182,0.307,0.282$, and 0.194 for the watersheds $\mathrm{SW}_{1}, \mathrm{SW}_{2}, \mathrm{SW}_{3}, \mathrm{SW}_{4}, \mathrm{SW}_{5}$, and $\mathrm{SW}_{6}$ respectively (Table 5). The factors affecting the drainage density are the length of the streams, climate, weathering, and permeability, etc; [54]. The drainage density also affects the travel time of runoff in the watershed [55]. The results show that low drainage density which might be due to the impermeable surface or subsurface materials with high vegetation cover and low catchment relief (Fig. 4c). The drainage texture $\left(R_{t}\right)$ of the subwatersheds of the Kuttiyadi river is $0.119,0.079,0.066,0.069,0.051$, and 0.077 for the subwatersheds $\mathrm{SW}_{1}, \mathrm{SW}_{2}, \mathrm{SW}_{3}, \mathrm{SW}_{4}, \mathrm{SW}_{5}$, and $\mathrm{SW}_{6}$ respectively (Table 5). The result shows the subwatersheds have a very fine drainage texture so that all the subwatersheds show a longer duration to the peak runoff. The results also show the watershed has very low relief with a low drainage density [42]. Stream frequency is defined as the total number of streams of all orders per unit watershed area. The stream frequency $\left(F_{s}\right)$ is related to the watershed infiltration rate and capacity, permeability, and relief $[14,18]$. The result shows that the $S_{2}$ watershed has the minimum stream frequency among all the subwatersheds. This might be due to the fact that the watershed has a high 
relative relief and it contains some rocky terrain as well (Table 1 and 5). The $S W_{4}$ shows high stream frequency as compared to other watersheds. This may be due to the watershed having comparatively low relief and having more vegetation as compared to the others (Table 1 and 5). Overall the stream frequency of the watershed is low because the watershed of the Kuttiyadi river is covered by adequate vegetation and loamy soil such that the catchment has a very good infiltration rate and infiltration capacity. So, the early rise in the hydrograph peak is not possible due to the low stream frequency of the watershed ie; the runoff will take more time to reach the watershed outlet [56-58]

Length of overland flow $\left(\mathrm{L}_{\mathrm{g}}\right)$ is one of the most independent parameters which affect both hydrological and hydrographical development of the watersheds $[40,59]$. The computed values of $\mathrm{L}_{\mathrm{g}}$ for the subwatersheds $\mathrm{SW}_{1}, \mathrm{SW}_{2}$, $\mathrm{SW}_{3}, \mathrm{SW}_{4}, \mathrm{SW}_{5}$, and $\mathrm{SW}_{6}$ are 3.46, 3.26, 2.47, 1.63, 2.40, and 5.57 respectively (Table 5). The larger values of $\mathrm{L}_{\mathrm{g}}$ which is shown by all the subwatersheds indicate gentle slopes with longer flow paths for the runoff. Constant channel maintenance $(C)$ which is reciprocal of the Drainage density $\left(D_{d}\right)$ indicates how much watershed drainage area is required to maintain a unit length of a channel [60]. The computed values of $C$ for the subwatersheds $\mathrm{SW}_{1}, \mathrm{SW}_{2}, \mathrm{SW}_{3}$, $\mathrm{SW}_{4}, \mathrm{SW}_{5}$, and $\mathrm{SW}_{6}$ are $6.92,6.51,5.48,3.26,4.80$, and 5.14 respectively (Table 5 ). The large values of the $\mathrm{C}$ which is shown by all the subwatersheds indicate the watershed has high resistive soils, with high vegetation and comparatively a plane area which also indicates the subwatersheds are less prone to erosion (Fig. 4b and 4d).

The elongation ratio $\left(R_{e}\right)$ depends on a wide variety of climate, geology, and relief of a watershed. If $R_{e}$ is greater than 0.9 then the watershed lies in the category of the circular watershed, if $R_{e}$ lies in between 0.9-0.7 then it is categorized under an oval watershed and if $\mathrm{R}_{\mathrm{e}}$ lies less than 0.7 then the watershed is called elongated in shape [14]. The computed values of $\mathrm{R}_{\mathrm{e}}$ show the $\mathrm{SW}_{4}$ has larger elongation in shape as compared to other watersheds (Table 5), and it shows a larger concentration-time for the hydrograph peak for a particular storm event. The form factor $\left(F_{f}\right)$ of a watershed indicates the duration of runoff to reach the outlet. The high values of form factors indicate high peak flows with shorter duration whereas the low form factor indicates the lower peak flow with longer duration [61]. The form factor of the subwatersheds of the Kuttiyadi river is $0.446,0.439,0.292,0.212,0.171$, and 0.363 for the watersheds $S_{1}, S W_{2}$, $\mathrm{SW}_{3}, \mathrm{SW}_{4}, \mathrm{SW}_{5}$, and $\mathrm{SW}_{6}$ respectively (Table 5). Results indicate the subwatersheds have low values of form factors which show that the lower peak flows so the runoff will take a large time to reach the outlet of the watershed. Result also shows the watersheds are elongated in shape and they are quite capable to manage flood flows as compare to circular watersheds.

The compactness coefficient $\left(\mathrm{C}_{\mathrm{c}}\right)$ expresses the relationship of a watershed with that of a circular watershed having the same area. A drainage channel in the circular watershed drains the water in the shortest period as compared to the other shapes to the outlet i.e. the peak of a hydrograph will occur in the shortest period after a storm event $[62,63]$. If $\mathrm{C}_{\mathrm{c}}$ approaches unity, the watershed behaves like a completely circular watershed and if Cc is greater than 1 watershed shows more deviation from its circular shape [64]. The computed values of $C_{c}$ are greater than one suggesting that all the watersheds deviate from the circular shape and show some elongation. The $\mathrm{C}_{\mathrm{c}}$ value of 3.49 for the $\mathrm{SW}_{4}$ shows higher elongation in its shape and consequently, it will have the longest concentration time to reach the water at the watershed outlet (Table 5).

The circulatory Ratio $\left(R_{c}\right)$ of the watershed influences the frequency and length of the streams, geological structures, LULC, relief, climate, and slope [53]. The computed values of $R_{c}$ for the subwatersheds $S_{1}, S W_{2}, S W_{3}, S W_{4}, S W_{5}$, and $\mathrm{SW}_{6}$ ranges from 0.064 to 0.436 (Table 5). The $\mathrm{SW}_{1}, \mathrm{SW}_{2}, \mathrm{SW}_{3}$, and $\mathrm{SW}_{6}$ show a large value of $\mathrm{R}_{\mathrm{c}}$ as compare to $\mathrm{SW}_{4}$ and $S_{5}$. The low values of $R_{c}$ might be due to the low relief and gentle slope shown by the $S_{4}$ and $S_{5}$ shows the larger time of concentration for the peak runoff and the rest of the watershed shows less time of concentration [14]. Also, low values of $\mathrm{R}_{\mathrm{C}}$ indicate the watershed having permeable surface and sub-surface materials which allows

Page $10 / 20$ 
infiltration and contributes to the base flow. Generally for any watershed, if the value of the Rotundity factor $\left(\mathrm{R}_{\mathrm{f}}\right)$ approaches unity it indicates the perfectly circular watershed [46]. The computed value of the $R_{f}$ ranges from 0.56 to 1.17 which indicates all the subwatersheds are elongated in shape (Table 5). The $\mathrm{SW}_{4}$ shows a very large elongation in its shape as compared to the other subwatersheds. The results show the watersheds having week stratum and permeable surface and sub-surface material which allows infiltration of the water and approaches to a flatter hydrograph with a larger time of concentration. The rate of flow and the erosion rate of a watershed along with the main river is largely affected by the shape index $\left(\mathrm{S}_{\mathrm{i}}\right)[40,54]$. It depends on the relief and length of the watershed. If a computed value of the shape index approaches to unity, the watersheds show maximum erosion rate. The computed values of $S_{i}$ are 1.72, 2.272, 2.480, 3.457, 3.563, and 2.698 for the subwatersheds $\mathrm{SW}_{1}, \mathrm{SW}_{2}, \mathrm{SW}_{3}, \mathrm{SW}_{4}, \mathrm{SW}_{5}$, and $\mathrm{SW}_{6}$ respectively (Table 5). The $\mathrm{SW}_{1}$ and $\mathrm{SW}_{2}$ shows a higher erosion rate with very little time of concentration and $\mathrm{SW}_{4}$ and $\mathrm{SW}_{5}$ shows less erosion rate and larger concentration-time as compared to other subwatersheds [46].

Table 5

Computed values of the aerial aspect of the geo-morphometric parameters for the sub-watershed of Kuttiyadi river

\begin{tabular}{|c|c|c|c|c|c|c|c|c|c|c|c|}
\hline S.No & $\mathrm{D}_{\mathrm{d}}$ & $F_{s}$ & $\mathrm{~T}$ & $\mathrm{~L}_{\mathrm{g}}$ & C & $S_{i}$ & $F_{f}$ & $\mathrm{C}_{\mathrm{c}}$ & $\mathbf{R}_{\mathbf{e}}$ & $\mathbf{R}_{\mathrm{c}}$ & $R_{f}$ \\
\hline $\mathrm{SW}_{1}$ & 0.145 & 0.056 & 0.119 & 3.46 & 6.92 & 1.762 & 0.446 & 1.513 & 0.754 & 0.436 & 0.560 \\
\hline $\mathrm{SW}_{2}$ & 0.154 & 0.046 & 0.079 & 3.26 & 6.51 & 2.272 & 0.439 & 1.626 & 0.747 & 0.378 & 0.569 \\
\hline $\mathrm{SW}_{3}$ & 0.182 & 0.06 & 0.066 & 2.74 & 5.48 & 2.480 & 0.292 & 1.818 & 0.609 & 0.302 & 0.857 \\
\hline $\mathrm{SW}_{4}$ & 0.307 & 0.117 & 0.069 & 1.63 & 3.26 & 3.457 & 0.212 & 3.942 & 0.520 & 0.064 & 1.178 \\
\hline $\mathrm{SW}_{5}$ & 0.208 & 0.073 & 0.051 & 2.40 & 4.80 & 3.563 & 0.171 & 3.175 & 0.467 & 0.099 & 0.984 \\
\hline $\mathrm{SW}_{6}$ & 0.194 & 0.089 & 0.077 & 2.57 & 5.14 & 2.698 & 0.363 & 1.798 & 0.679 & 0.309 & 0.689 \\
\hline
\end{tabular}

\subsection{Surface Runoff and Sediment Production Rates}

Runoff from the surface of a watershed is dependent on several hydrological parameters, including precipitation, evaporation, infiltration, and transpiration, which are themselves related to climatic conditions, lithology, structure, relief, and slopes [3]. From the analysis of the aerial aspect of geo-morphometric parameters, the volume of surface runoff per unit area of the subwatersheds are found as 32.88, 26.02, 16.15, 2.13, 7.42, and $16.57 \mathrm{~km}^{2}-\mathrm{cm} / \mathrm{km}^{2} \mathrm{for} \mathrm{SW}_{1}, \mathrm{SW}_{2}, \mathrm{SW}_{3}$, $\mathrm{SW}_{4}, \mathrm{SW}_{5}$, and $\mathrm{SW}_{6}$ respectively (Fig. 5). The subwatersheds were categorized as a zone of low runoff to high runoff based on the estimated surface runoff values (Fig. $6 a$ ). The $S W_{4}, S_{5}$, and $S W_{6}, S_{3}$ will be categorized under the zone of low and medium surface runoff respectively which may be due to the elongation of watersheds, low drainage density, and reasonable geological control over the surface runoff pattern while the $\mathrm{SW}_{1}$ and $\mathrm{SW}_{2}$ were categorized under the zone of high surface runoff which is maybe due to the less elongation, high drainage density, and the subwatersheds doesn't have reasonable geological control over the pattern of surface runoff. The accumulated estimated surface runoff at the watershed outlet is $1019.7 \mathrm{~mm}$ which is nearly equal to the measured surface runoff as $944.03 \mathrm{~mm}$ for the Kuttiyadi watershed [66]. The Sediment production rate of the subwatersheds of the Kuttiyadi river are estimated as $0.017,0.010,0.0036,0.0004,0.0006$ and, 0.0038 (Ha-m/100.km²/year) for $\mathrm{SW}_{1}, \mathrm{SW}_{2}, \mathrm{SW}_{3}, \mathrm{SW}_{4}, \mathrm{SW}_{5}$, and $S_{6} W_{6}$ respectively (Fig. 5). The categorization of the SPR shows $S_{1}$ is more prone to soil erosion followed by $S W_{2}$ whereas, $\mathrm{SW}_{3}, \mathrm{SW}_{4}, \mathrm{SW}_{5}$, and $\mathrm{SW}_{6}$ are less prone to soil erosion (Fig. $6 \mathrm{~b}$ ). The high erosion rate of the sub-watershed was due to the combination of steep slopes, the presence of sandy loam and clay loam soils, and less forest cover over the subwatersheds. The subwatersheds which are less prone to soil erosion having adequate high forest cover and 
gentle slope over the watersheds. The findings demonstrate a strong relationship between the geo-morphometric parameters and terrain slope in the watershed which is sensitive for the generation of surface runoff and sediment production. As a result, it is vital to emphasize these parameters in developing regional systems intended to manage, protect, and develop land resources. According to the numerical model used in this study, the drainage characteristics of basins have a direct influence on erosion rates and over sediment yield. Despite the fact that the effect of catchment land use on the overall sediment yields of rivers around the world is less clear, there have been some instances of both increasing and decreasing sediment yields. Studies of the impacts of both land-use change and climate change on river sediment loads must often separate out their impacts, though they may be closely linked. Understanding the role of sediment production rate within a drainage basin inevitably means understanding the linkages between land use, erosion, and sediment yield within a river basin.

\section{Conclusion}

The Remote Sensing (RS) along with Geographic Information System (GIS) tools are the most reliable and convenient tools for computing the geo-morphometric parameters. Geomorphological parameters are considered to be the preliminary indicator of geology, relief, slope, climate, and hydrodynamics of a river system. In watershed management and hazard mitigation, the determination of the behavior of stream networks and their interactions are crucial factors. In this study geo-morphometric analysis of the linear, aerial, and relief aspects of subwatersheds has been performed. According to the study, it is concluded that the hydrologic response of the sub-watershed of the Kuttiyadi river can be categorized as semi-dendritic to dendritic with the highest order of 4th. The analysis of the linear aspects of the subwatersheds shows that the whole area of study has a uniform lithology makes the hydrological response of the subwatersheds is a primary function of the topographic and geomorphologic parameters and the vegetation conditions which exist on the subwatersheds and also the spatial variability in the geo- morphometric parameters influence the hydrological behavior of these subwatersheds. The aerial and relief aspects of the subwatersheds of the Kuttiyadi river show fine drainage texture, gentle slopes, delayed peak flow, flatter hydrograph, and large time of concentration which are quite capable to manage flash floods. The mathematical model demonstrates $\mathrm{SW}_{1}$ will be categorized under the zone of high surface runoff and more prone to soil erosion followed by $\mathrm{SW}_{2}$ while $\mathrm{SW}_{4}$ and $\mathrm{SW}_{5}$ are categorized under the zone of less surface runoff and less prone to soil erosion. The accumulated surface runoff at the outlet of the Kuttiyadi river is found as $1019.7 \mathrm{~mm}$ which is nearly equal to the $944.03 \mathrm{~mm}$. Therefore, preventing further erosion of the land in these watersheds is necessary for the preservation of the ecological environment and development of the area. This primary investigation plays an important role in flooding vulnerability assessments and flood risk assessments also in the downstream regions; it will supply the information and basic knowledge to the decision and policymakers to develop the pre-assessment for peak flooding and sustainable land-use policies.

\section{Declarations}

\section{Acknowledgment}

The research work was conducted as part of M.Tech. Dissertation work entitled, "Hydrological modeling of a catchment" under the supervision of Prof. Mohit Kumar. The authors thank Director Punjab Engineering College (Deemed to be University) and PG coordinator (Water Resources Engineering Dept.), Punjab Engineering College (Deemed to be University), Sector 12, Chandigarh, 160012, India for providing facilities to make the present study possible.

\section{Competing/ Conflict of interests}

The authors declare that there is no conflict of interest in this study 


\section{Authors' contributions}

Kuldeep Singh Rautela led the development and design of the manuscript, Varun Khjuria analyzed the parameters and writing under the supervision of Prof. Mohit Kumar and Dr. M.A. Alam. All authors read and approved the final manuscript.

\section{References}

1. Sofi MS, Bhat SU, Rashid I, Kuniyal JC. The natural flow regime: A master variable for maintaining river ecosystem health. Ecohydrology. 2020;13(8):e2247. https://doi.org/10.1002/eco.2247

2. Piao S, Ciais P, Huang Y, Shen Z, Peng S, Li J, Zhou L, Liu H, Ma Y, Ding Y, Friedlingstein P. The impacts of climate change on water resources and agriculture in China. Nature. 2010;467(7311):43-51.

https://doi.org/10.1038/nature09364

3. Sofi MS, Rautela KS, Bhat SU, Rashid I, Kuniyal JC. Application of Geomorphometric Approach for the Estimation of Hydro-sedimentological Flows and Cation Weathering Rate: Towards Understanding the Sustainable Land Use Policy for the Sindh Basin, Kashmir Himalaya. Water, Air, \& Soil Pollution. 2021;232(7):1-1. https://doi.org/10.1007/s11270-021-05217-w

4. Oki T, Kanae S. Global hydrological cycles and world water resources. science. 2006;313(5790):106872..https://doi.org/10.1126/science.1128845

5. Wang GQ, Zhang JY, Pagano TC, Lin JL, Liu CS. Identifying contributions of climate change and human activity to changes in runoff using epoch detection and hydrologic simulation. Journal of Hydrologic Engineering. 2013;18(11):1385-92. https://doi.org/10.1061/(ASCE)HE.1943-5584.0000559

6. Chen J, Theller L, Gitau MW, Engel BA, Harbor JM. Urbanization impacts on surface runoff of the contiguous United States. Journal of Environmental Management. 2017;187:470-81. https://doi.org/10.1016/j.jenvman.2016.11.017

7. Dutta S. Soil erosion, sediment yield and sedimentation of reservoir: a review. Modeling Earth Systems and Environment. 2016;2(3):1-8. https://doi.org/10.1007/s40808-016-0182-y

8. Kondolf GM, Gao Y, Annandale GW, Morris GL, Jiang E, Zhang J, Cao Y, Carling P, Fu K, Guo Q, Hotchkiss R. Sustainable sediment management in reservoirs and regulated rivers: Experiences from five continents. Earth's Future. 2014;2(5):256-80.. https://doi.org/10.1002/2013EF000184

9. Talbot CJ, Bennett EM, Cassell K, Hanes DM, Minor EC, Paerl H, Raymond PA, Vargas R, Vidon PG, Wollheim W, Xenopoulos MA. The impact of flooding on aquatic ecosystem services. Biogeochemistry. 2018;141(3):43961.https://doi.org/10.1007/s10533-018-0449-7

10. Ouillon S. Why and how do we study sediment transport? Focus on coastal zones and ongoing methods. Water, 2018; 10: 390. https://doi.org/10.3390/w10040390

11. Turner BL. The earth as transformed by human action. The Professional Geographer. 1988 Aug 1;40(3):340-1.

12. Agarwal CS. Study of drainage pattern through aerial data in Naugarh area of Varanasi district, UP. Journal of the Indian Society of Remote Sensing. 1998;26(4):169-75. https://doi.org/10.1007/BF02990795

13. Hajam RA, Hamid A, Ahmad DN, Bhat SU. Morphometric analysis of Vishav drainage basin using geo-spatial technology (GST). International Research Journal of Geology and Mining. 2013;3(3):136-46. http://www.interesjournals.org/ IRJGM

14. Altaf F, Meraj G, Romshoo SA. Morphometric analysis to infer hydrological behaviour of Lidder watershed, Western Himalaya, India. Geography Journal. 2013;2013. https://doi.org/10.1155/2013/178021

15. Prabhakaran A, Raj NJ. Drainage morphometric analysis for assessing form and processes of the watersheds of Pachamalai hills and its adjoinings, Central Tamil Nadu, India. Applied water science. 2018;8(1):1-9. 
https://doi.org/10.1007/s13201-018-0646-5

16. Ozdemir H, Bird D. Evaluation of morphometric parameters of drainage networks derived from topographic maps and DEM in point of floods. Environmental geology. 2009;56(7):1405-15.. https://doi.org/10.1007/s00254-0081235-y

17. Nag SK. Morphometric analysis using remote sensing techniques in the Chaka sub-basin, Purulia district, West Bengal. Journal of the Indian society of remote sensing. 1998;26(1):69-76.. https://doi.org/10.1007/BF03007341

18. Mahala A. The significance of morphometric analysis to understand the hydrological and morphological characteristics in two different morpho-climatic settings. Applied Water Science. 2020;10(1):1-6.. https://doi.org/10.1007s13201-019-1118-2

19. Iqbal M, Sajjad H, Bhat FA. Morphometric analysis of Shaliganga sub catchment, Kashmir Valley, India using geographical information system. Int J Eng Trends Technol. 2013;4(1):10-21.

http://www.ijettjournal.org/archive/ijett-v4i1p202

20. Michailidi EM, Antoniadi S, Koukouvinos A, Bacchi B, Efstratiadis A. Timing the time of concentration: shedding light on a paradox. Hydrological sciences journal. 2018;63(5):721-

40.https://doi.org/10.1080/02626667.2018.1450985

21. Chandniha SK, Kansal ML. Prioritization of sub-watersheds based on morphometric analysis using geospatial technique in Piperiya watershed, India. Applied Water Science. 2017;7(1):329-38.. https://doi.org/10.1007/s13201014-0248-9

22. Roth G, La Barbera P, Greco M. On the description of the basin effective drainage structure. Journal of hydrology. 1996;187(1-2):119-35. https://doi.org/10.1016/S0022-1694(96)03090-9

23. Lamarre H, Roy AG. A field experiment on the development of sedimentary structures in a gravel-bed river. Earth Surface Processes and Landforms: The Journal of the British Geomorphological Research Group. 2008;33(7):106481.https://doi.org/10.1002/esp.1602

24. Khatri N, Tyagi S. Influences of natural and anthropogenic factors on surface and groundwater quality in rural and urban areas. Frontiers in life science. 2015;8(1):23-39. https://doi.org/10.1080/21553769.2014.933716

25. Quan B, Römkens MJ, Li R, Wang F, Chen J. Effect of land use and land cover change on soil erosion and the spatio-temporal variation in Liupan Mountain Region, southern Ningxia, China. Frontiers of Environmental Science \& Engineering in China. 2011;5(4):564-72. https://doi.org/10.1007/s11783-011-0348-9

26. Mythili G, Goedecke J. Economics of land degradation in India. InEconomics of land degradation and improvement-a global assessment for sustainable development, Springer, Cham; 2016; (pp. 431-469.

27. Dhawan V. Water and agriculture in India: background paper for the South Asia expert panel during the Global Forum for Food and Agriculture (GFFA) 2017; 28: 1-28.

https://www.oav.de/fileadmin/user_upload/5_Publikationen/5_Studien/170118_Study_Water_Agriculture_India.pdf

28. Ahmed F, Srinivasa RK. Geomorphometric analysis for estimation of sediment production rate and run-off in Tuirini watershed, Mizoram, India. International Journal of Remote Sensing Applications. 2015;5:67-77.

https://doi.org/10.14355/ijrsa.2015.05.008

29. Pawar AD, Sarup J, Mittal SK. Application of GIS and RS for Morphometric Analysis of Upper Bhima Basin: A Case Study. Journal of The Institution of Engineers (India): Series A. 2014;95(4):249-57.https://doi.org/10.1007/s40030014-0097-4

30. Dang AT, Kumar L. Application of remote sensing and GIS-based hydrological modelling for flood risk analysis: a case study of District 8, Ho Chi Minh city, Vietnam. Geomatics, Natural Hazards and Risk. 2017;8(2):1792-

811.https://doi.org/10.1080/19475705.2017.1388853

Page $14 / 20$ 
31. Swetha TV, Gopinath G. Landslides susceptibility assessment by analytical network process: a case study for Kuttiyadi river basin (Western Ghats, southern India). SN Applied Sciences. 2020;2(11):1-2. https://doi.org/10.1007/s42452-020-03574-5

32. Faniran A. The index of drainage intensity: a provisional new drainage factor. Aust J Sci. 1968;31(9):326-30.

33. Miller VC. A Quantitative geomorphic study of drainage basin characteristics in the Clinch Mountain area, Virginia and Tennessee, Tech. Rep. 3 NR 389-402, Columbia University, Department of Geology, ONR, New York, NY, USA; 1953.

34. Pareta K, Pareta U. Quantitative morphometric analysis of a watershed of Yamuna basin, India using ASTER (DEM) data and GIS. International journal of Geomatics and Geosciences. 2011;2(1):248-69.

https://doi.org=10.1.1.298.2002

35. Suresh M, Sudhakar S, Tiwari KN, Chowdary VM. Prioritization of watersheds using morphometric parameters and assessment of surface water potential using remote sensing. Journal of the indian society of remote sensing. 2004;32(3):249-59. https://link.springer.com/article/10.1007/BF03030885

36. Sameena M, Krishnamurthy J, Jayaraman V, Ranganna G. Evaluation of drainage networks developed in hard rock terrain. Geocarto International. 2009 Oct 1;24(5):397-420. https://doi.org/10.1080/10106040802601029

37. Strahler AN. Quantitative analysis of watershed geomorphology. Eos, Transactions American Geophysical Union. 1957;38(6):913-20. https://doi.org/10.1029/TR038i006p00913

38. Strahler AN. Part II. Quantitative geomorphology of drainage basins and channel networks. Handbook of Applied Hydrology: McGraw-Hill, New York; 1964:4-39.

39. Horton RE. Erosional development of streams and their drainage basins; hydrophysical approach to quantitative morphology. Geological society of America bulletin. 1945;56(3):275-370. https://doi.org/10.1130/00167606(1945)56[275:EDOSAT]2.0.CO;2

40. Horton RE. Drainage-basin characteristics. Eos, transactions american geophysical union. 1932;13(1):350-61.

41. Schumm SA. Evolution of drainage systems and slopes in badlands at Perth Amboy, New Jersey. Geological society of America bulletin. 1956;67(5):597-646. https://doi.org/10.1130/00167606(1956)67[597:EODSAS]2.0.C0;2

42. Smith KG. Standards for grading texture of erosional topography. American journal of Science. 1950;248(9):65568. https://doi.org/10.2475/ajs.248.9.655

43. Gravelius H. Grundrifi der Gesamten Gewcisserkunde. Band I: Flufikunde. Compendium of Hydrology, vol. I. Rivers. German. Goschen, Berlin. 1914.

44. Chorley R.J, Malm DEC, Pogorzelski HA. A new standard for measuring drainage basin shape. American Journal of Science,1957; 255:138-141.

45. Jose CS, Das DC. Geomorphic prediction models for sediment production rate and intensive priorities of watersheds in Mayurakshi catchment. InProc. of International Symp. On Hydrological Aspects of Mountainous Watersheds, School of Hydrology, UOR, Roorkee, 1982;1:15-33.

46. Rymbai PN, Jha LK. Estimation of sediment production rate of the Umbaniun Micro-watershed, Meghalaya, India. Journal of Geography and Regional Planning. 2012;5(11):293-7. https://doi.org/10.5897/JGRP12.024.

47. Ahmed KB, Sanchez M. A study of the factors and processes involved in the sedimentation of Tarbela reservoir, Pakistan. Environmental earth sciences. 2011;62(5):927-33. https://doi.org/10.1007/s12665-010-0578-3

48. Waikar ML, Nilawar AP. Morphometric analysis of a drainage basin using geographical information system: a case study. Int J Multidiscip Curr Res. 2014;2(2014):179-84. 
49. Manjare BS, Padhye MA, Girhe SS. Morphometric Analysis of a Lower Wardha River sub basin of Maharashtra, India Using ASTER DEM Data and GIS. In15th Esri India User Conference 2014. pp. 1-13.

50. Howard AD. Role of hypsometry and planform in basin hydrologic response. Hydrological Processes. 1990;4(4):373-85. https://doi.org/10.1002/hyp.3360040407

51. Babu K. J., Sreekumar S. \& Aslam A. 2016 Babu KJ, Sreekumar S, Aslam A. Implication of drainage basin parameters of a tropical river basin of South India. Applied Water Science. 2016;6(1):67-75. https://doi.org/10.1007/s13201-014-0212-8

52. Asfaw D, Workineh G. Quantitative analysis of morphometry on Ribb and Gumara watersheds: Implications for soil and water conservation. International Soil and Water Conservation Research. 2019;7(2):150-7. https://doi.org/10.1016/j.iswcr.2019.02.003

53. Rai PK, Mohan K, Mishra S, Ahmad A, Mishra VN. A GIS-based approach in drainage morphometric analysis of Kanhar River Basin, India. Applied Water Science. 2017;7(1):217-32. https://doi.org/10.1007/s13201-014-0238-y

54. Fenta AA, Yasuda H, Shimizu K, Haregeweyn N, Woldearegay K. Quantitative analysis and implications of drainage morphometry of the Agula watershed in the semi-arid northern Ethiopia. Applied Water Science. 2017;7(7):3825-40. https://doi.org/10.1007/s13201-017-0534-4

55. Ogden FL, Raj Pradhan N, Downer CW, Zahner JA. Relative importance of impervious area, drainage density, width function, and subsurface storm drainage on flood runoff from an urbanized catchment. Water resources research. 2011;47(12). https://doi.org/10.1029/2011WR010550

56. Ghoneim EM, Arnell NW, Foody GM. Characterizing the flash flood hazards potential along the Red Sea coast of Egypt. IAHS-AISH publication. 2002:211-6.

57. Diakakis M. A method for flood hazard mapping based on basin morphometry: application in two catchments in Greece. Natural hazards. 2011;56(3):803-14. https://doi.org/10.1007/s11069-010-9592-8

58. Patton PC, Baker VR. Morphometry and floods in small drainage basins subject to diverse hydrogeomorphic controls. Water resources research. 1976;12(5):941-52. https://doi.org/10.1029/WR012i005p00941

59. Mokarram M, Sathyamoorthy D. Morphometric analysis of hydrological behavior of North Fars watershed, Iran. European Journal of Geography. 2015;6(4):88-106.

60. Sakthivel R, Raj NJ, Sivasankar V, Akhila P, Omine K. Geo-spatial technique-based approach on drainage morphometric analysis at Kalrayan Hills, Tamil Nadu, India. Applied Water Science. 2019;9(1):24. https://doi.org/10.1007/s13201-019-0899-7

61. Palaka R, Sankar GJ. Study of watershed characteristics using Google Elevation Service. Geospatial World. 2016; 112. https://www.geospatialworld.net/article/study-of-watershed-characteristics-using-google-elevation-service/

62. Ratnam KN, Srivastava YK, Rao VV, Amminedu E, Murthy KS. Check dam positioning by prioritization of microwatersheds using SYI model and morphometric analysis-remote sensing and GIS perspective. Journal of the Indian society of remote sensing. 2005;33(1):25-38. https://doi.org/10.1007/BF02989988

63. Javed A, Khanday MY, Ahmed R. Prioritization of sub-watersheds based on morphometric and land use analysis using remote sensing and GIS techniques. Journal of the Indian society of Remote Sensing. 2009;37(2):26174.https://doi.org/10.1007/s12524-009-0016-8

64. Adhikary PP, Dash CJ. Morphometric analysis of Katra watershed of Eastern Ghats: a GIS approach. International Journal of Current Microbiology and Applied Sciences, 2018;7(03): 1651-1665.

https://doi.org/10.20546/ijcmas.2018.703.198

65. Soni S. Assessment of morphometric characteristics of Chakrar watershed in Madhya Pradesh India using geospatial technique. Applied Water Science. 2017;7(5):2089-102. https://doi.org/10.1007/s13201-016-0395-2

66. Rautela K. Hydrological modeling of a catchment (Masters Dissertation), 2021. 


\section{Figures}

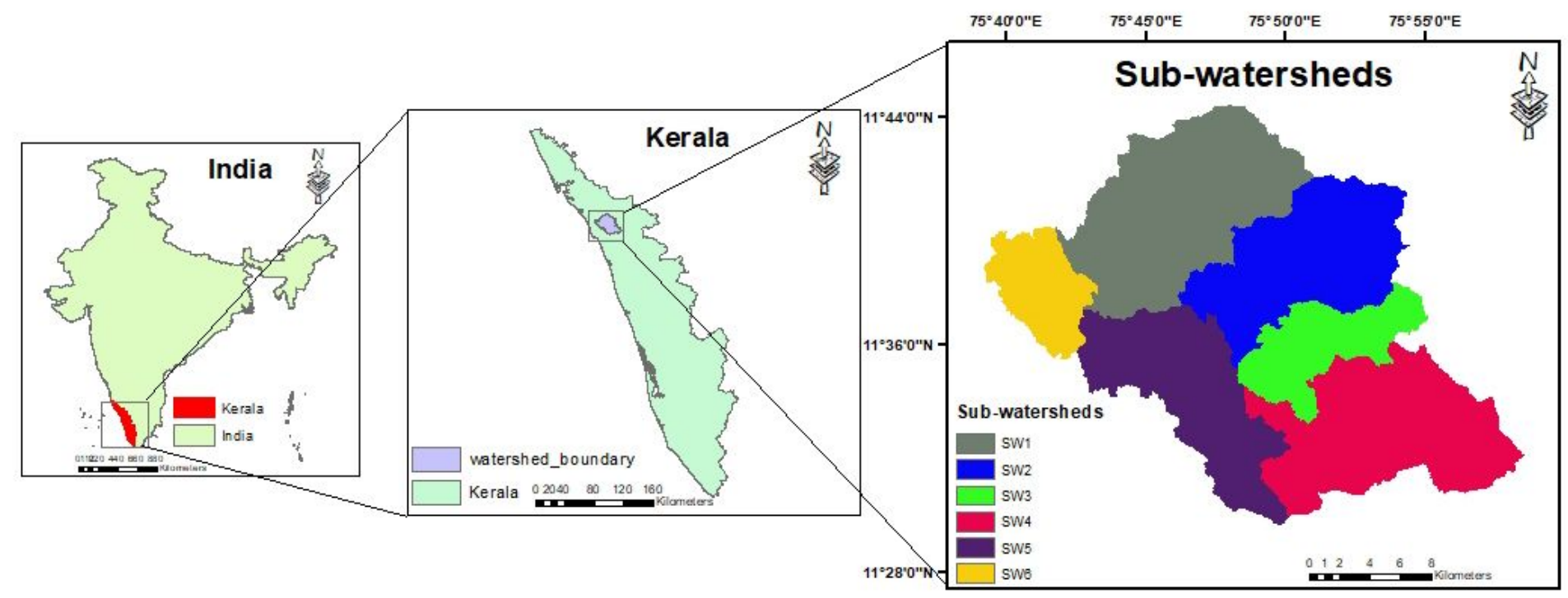

Figure 1

Location map of the study area

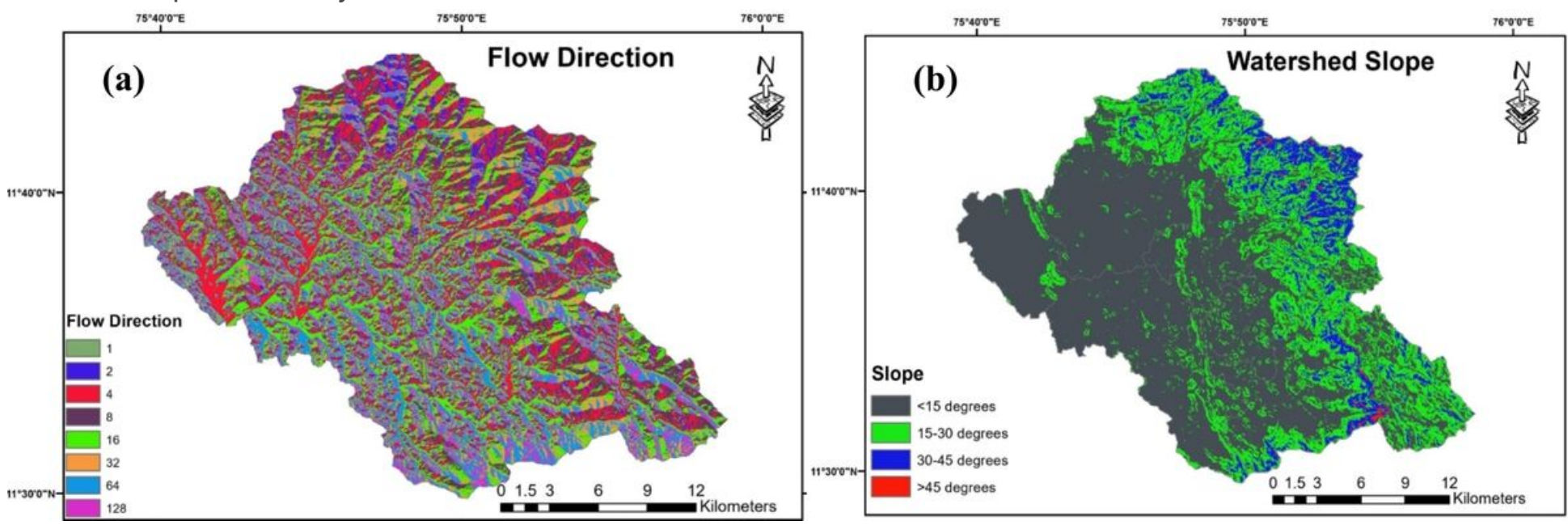

Figure 2

(a) Flow direction map and (b) classification of the slope of the Kuttiyadi river watershed 


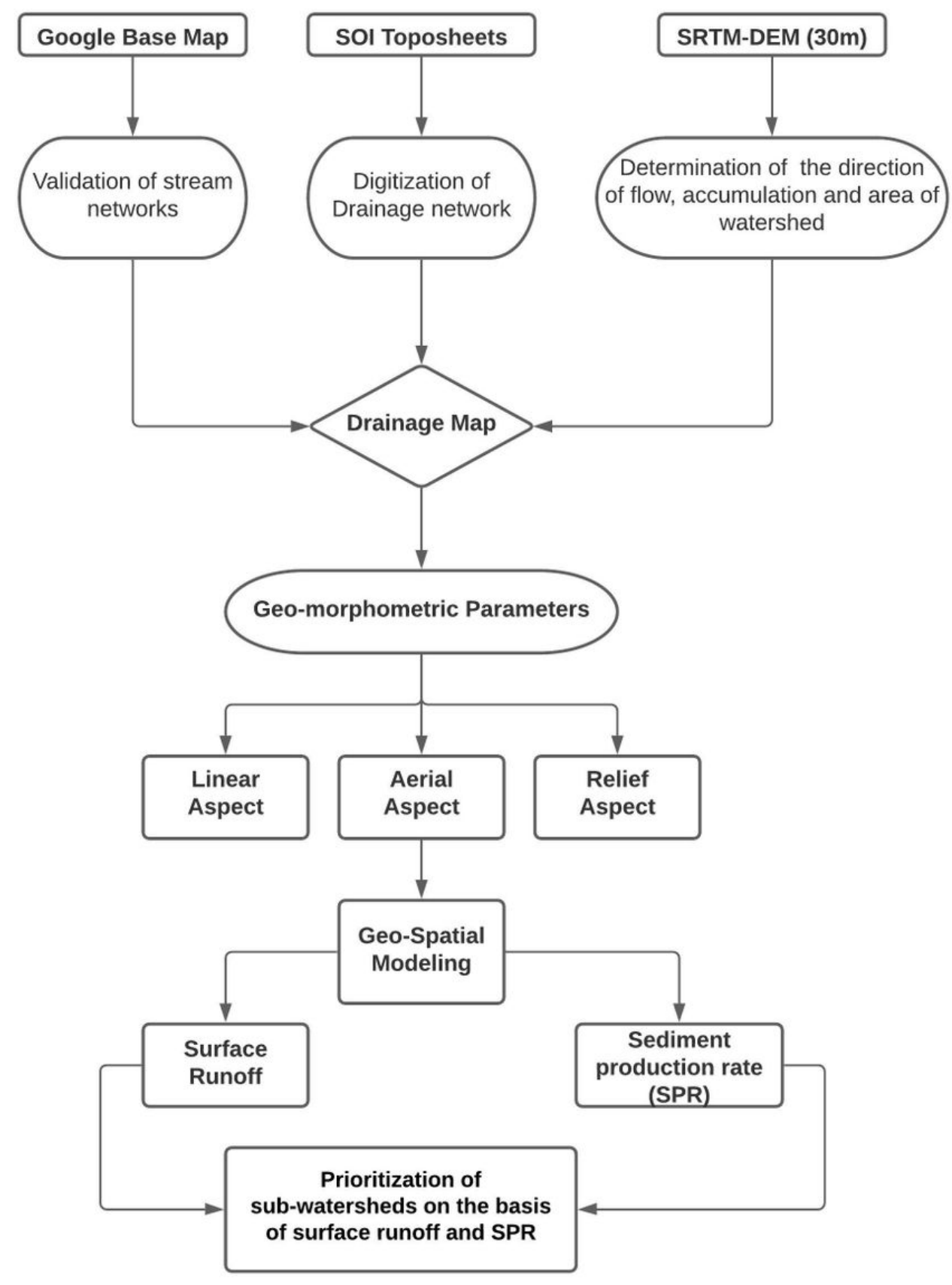

Figure 3

Methodology adopted for Prioritization of subwatersheds based on surface runoff and SPR 


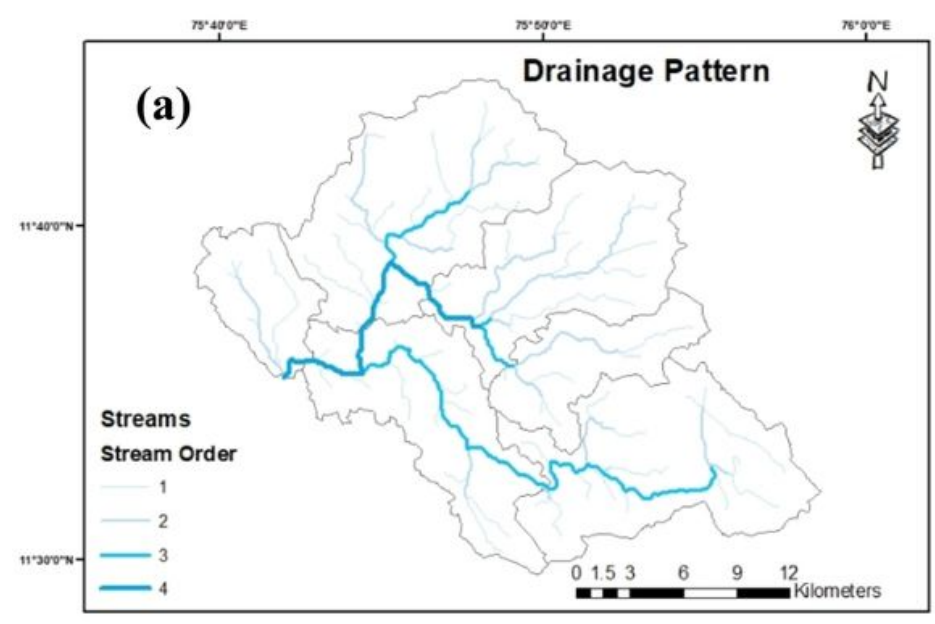

Ts:

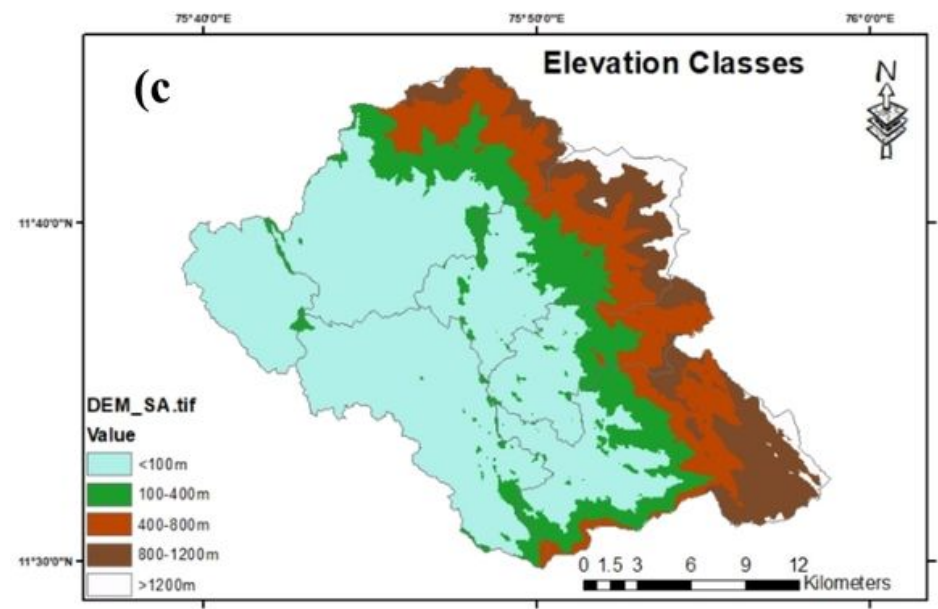

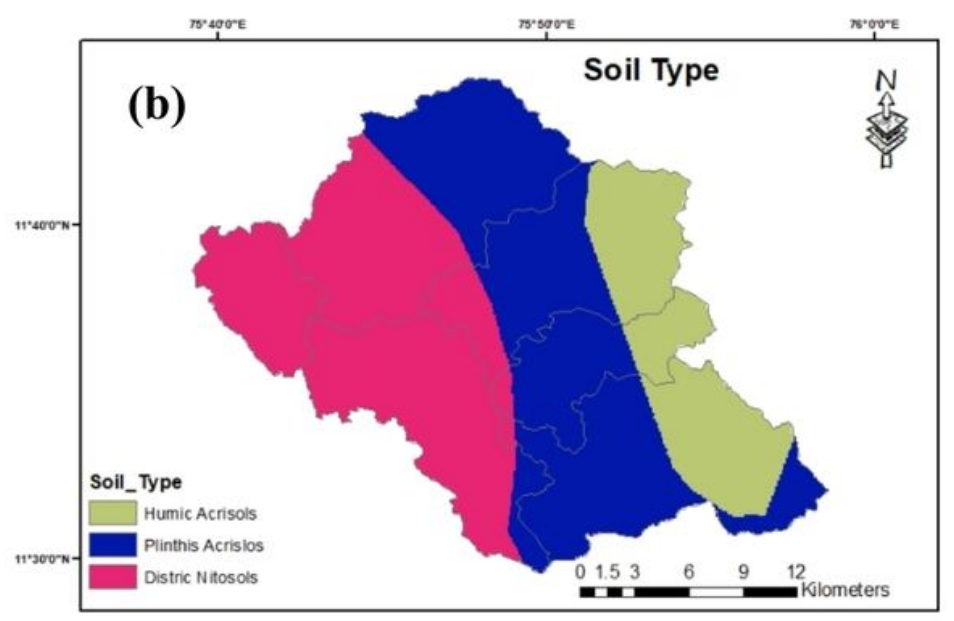

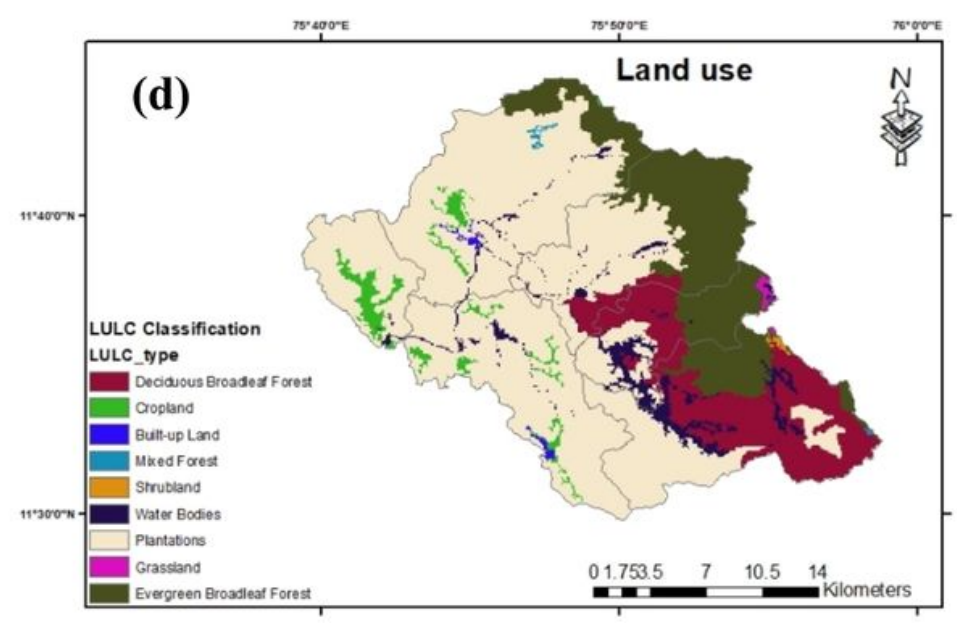

Figure 4

(a) Drainage map, (b) Soil map, (c) Elevation profile, and (d) land use pattern of the Kuttiyadi river watershed

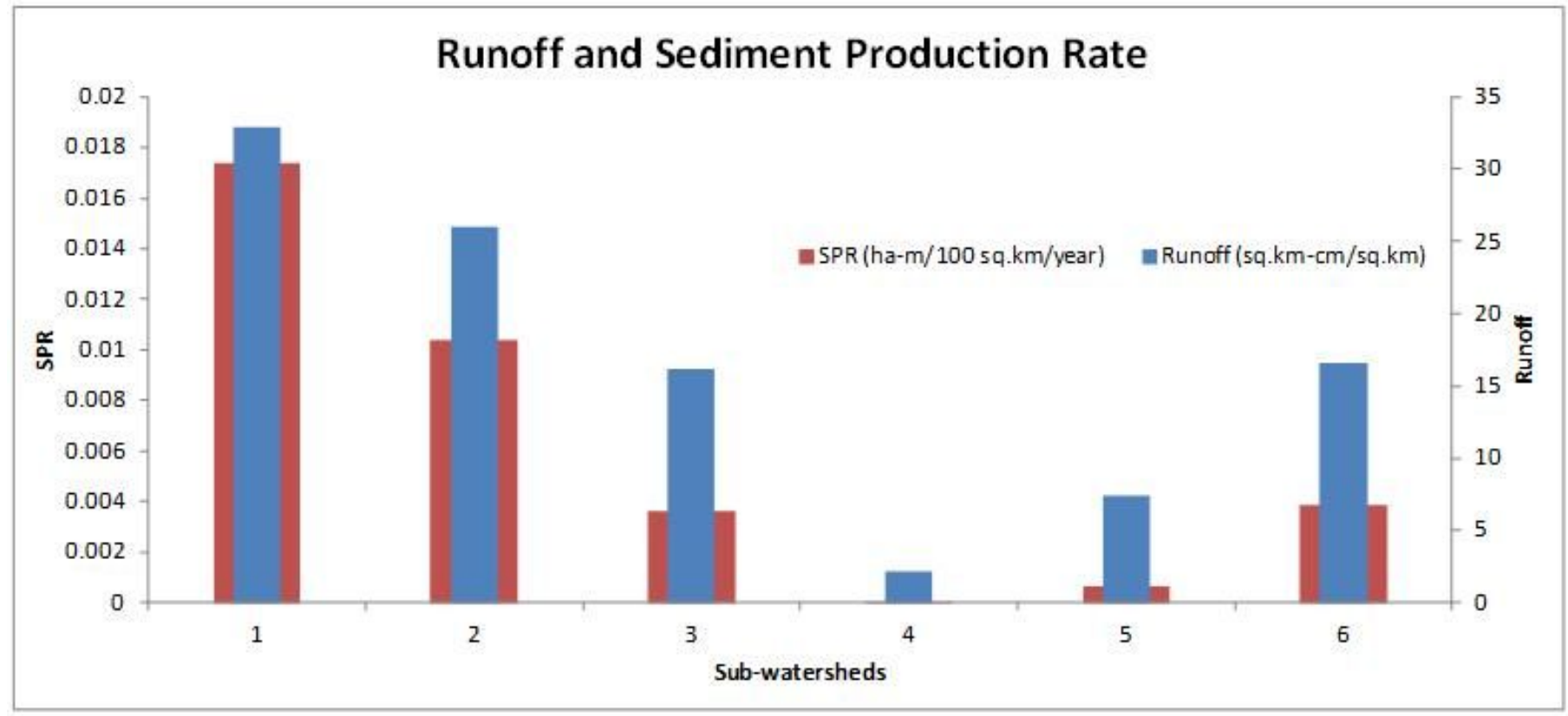

Figure 5

Estimated values of surface runoff and sediment production rate of the different sub-watershed of the Kuttiyadi river 

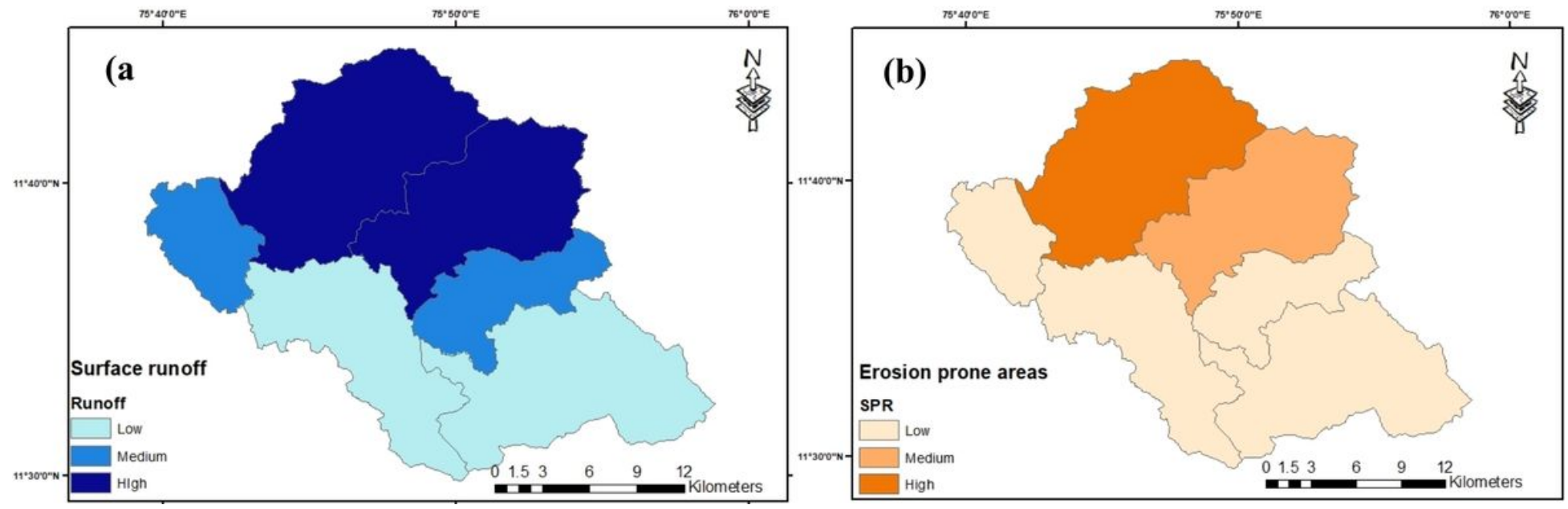

Figure 6

Classification and prioritization of the zones (a) surface runoff and (b) Erosion prone area of the different subwatershed of the Kuttiyadi river 